\title{
The Origins and Future of Rural Social Work
}

\section{Leon Ginsberg}

\begin{abstract}
Traced in the article are some of the author's reflections and experiences related to the origins of rural social work practice as well as some of the issues currently crucial for rural social work educators and practitioners. New data on U.S. rural demographics are provided. One factor with a special impact on rural life is the development of technology, which in some ways is changing the nature of rural community life. Integrated into this discussion of rural practice are observations about social work education in general and some of its current trends, reflective of the author's 50 years as an educator.
\end{abstract}

Keywords: Rural social work, social work education, West Virginia University

Close to fifty years ago, the Council on Social Work Education decided to include a session on rural social work in the 1968 Annual Program Meeting, to be held in Cleveland, one of the classically metropolitan areas of the United States. In that same year I was to be the new director of the Division of Social Work at West Virginia University in Morgantown, when there were only 50 accredited MSW programs. WVU was one of a handful of schools that organized its curriculum around "functional social work," based on the theories of Otto Rank, who although once a colleague of Sigmund Freud, had charted a different approach to psychiatry and psychology.

In order to provide a bit of historical context for those who became social workers more recently than I did, I should note that schools were oriented to one or the other of two ways of understanding human behavior and human services. I will thus begin with a discussion of these two orientations.

\section{Freudian vs. Rankian Social Work Orientations}

In the decades before the 1970s, almost all accredited schools of social work, meaning MSW programs because BSW programs were not accredited until 1975, were nominally associated with Freudian or "diagnostic" approaches to human services. I was educated in that approach at the Tulane University School of Social Work in New Orleans in the late 1950s. These distinctions are treated in NASW's various editions of The Encyclopedia of Social Work as well as books on the subject (Rozean, 1975).

In 1961, the CSWE Curriculum Policy Statement was changed significantly. It required schools to add to their curricula content from the social science disciplines. Schools, for the most part, continued to focus on the teachings and writings of Freud although often there were more current updates of the diagnostic theory. One of the most popular was the work of Erik H. Erikson and his concept of the eight stages of life laid out in his 1950 book, Childhood and Society, as well as in many subsequent works further developing his ideas. The impact of Erickson's epigenetic paradigm has

Leon Ginsberg, Ph.D., is Dean Emeritus of the College of Social Work at the University of South Carolina in Columbia, $\mathrm{SC}$

Copyright (C) 2014 Advances in Social Work Vol. 15 No. 1 (Spring 2014), 105-116 
demonstrated remarkable persistence over the years and continues to be an important conceptual lynchpin for a number of contemporary psychology programs. Erickson's continuing influence has also been evident in several recent doctoral dissertations on which I have served. Selma Fraiberg's (1959) work on early childhood was also popular with Freudian-oriented schools.

The Rankian school of thought also had an important impact in curriculum development of a number of schools of social work, especially at the University of Pennsylvania where the so-called "functional school" originated with the help of Rank himself (Rozean, 1975). For a time, the University of North Carolina and West Virginia University were also oriented to the "functional" school. Whether or not a school was "functional" or "diagnostic" often depended upon the point of view of its dean or director. At WVU, before I arrived, the director was Bernhard Scher, who had been associated with the University of Pennsylvania.

Eventually the philosophical disputes among the advocates of the Freudian vs. the Rankian points of view were largely forgotten in the wake of the hotly debated issues that emerged during the tumultuous 1960s. There was a heightened awareness of the influence of systemic factors on human behavior. A whole host of new concerns precipitated a growing awareness of the importance of incorporating sociological, anthropological, and political perspectives into mainstream social work theory and practice. Of all the societal issues that seemed to converge during this period, the explication of and action about ethnicity, color, and the civil rights movement were paramount. With increased pressures from both within and outside the profession to validate the efficacy of its interventions, this broader "systems" framework was complemented by approaches such as behavior modification based on learning principles espoused by B. F. Skinner (2011), social change theory (Ross \& Lappin, 1967), and the emergence of resilience theory and strengths-based social work (Saleebey, 2006).

The 1960s signaled the origin of the major civil rights battles including: The Brown v. Board of Education Supreme Court decision in 1954, requiring the desegregation of public schools; the Montgomery, Alabama bus boycott; and, the emergence of such leaders as Thurgood Marshall, who argued the Brown case before the Supreme Court and eventually became the first African American member of the Supreme Court, and, of course, Martin Luther King, whose birthday is now a national holiday. Some of that history of the civil rights movement was recently revisited in connection with the $50^{\text {th }}$ anniversary of the 1963 March on Washington.

Richard Cloward and Herman Stein's edited book, Social Perspectives on Behavior (1958), was the basis for much of the emphasis on the social science additions to the traditional social work curriculum. Cloward and Stein were social work professors at Columbia University, site of the first school of social work and often known at the time as the flagship school of social work. When Columbia did anything, most other schools fell into line.

So what orientation should the West Virginia University school adopt? The Rankian functional orientation was no longer in the mainstream. However, the faculty was oriented to it. The Freudian diagnostic orientation was perhaps becoming passé given the 
new emphasis on social issues and social science ideas. I asked Richard Lodge, then Dean of the Virginia Commonwealth University School of Social Work, who had nominated me for the West Virginia position and who had a history of affiliation with Penn, what he thought. (Lodge later became Executive Director of CSWE.) He suggested that the orientation ought to be rural social work - neither diagnostic nor functional. Eventually, many schools adopted such orientations reflecting settings or fields of practice rather than an allegiance to any particular theoretical frame of reference such as the Rankian or Freudian schools. The WVU School of Social Work selected rural social work as its primary field of practice for its MSW program.

Without belaboring the issues, making such a broad change as orienting the MSW program around rural social work had significant consequences. Over the Scher years most of the WVU school's field placements were all in agencies oriented to the theories of Rank - most of them outside the state. But the changes were made: placements were all to be in the Appalachian region, most in West Virginia.

Parenthetically, although many schools evolved away from the Freudian vs. Rankian orientations, not all did. Some schools continue to emphasize one or the other of the approaches. Even the Freudian adherents adopted some of the Rankian concepts such as limited time, identifying with the agency function, as well as others. And there continue to be agencies that focus on some of those approaches, neither of which makes much sense in disadvantaged and rural settings. Not long ago, I recommended one of my outstanding University of South Carolina students to an Eastern U.S. agency that was committed to Freudian approaches. She was lost during the interviews - had no idea what she was being asked.

The rural social work orientation of the West Virginia University School of Social Work culminated in a special session at the 1968 CSWE Annual Program Meeting in Cleveland, mentioned earlier, a session that was not only oversubscribed but which also attracted a wide range of participants from areas as disparate as New England, the South, and of course, Appalachia. From that early beginning, CSWE obtained grants and contracts to educate about rural social work. Agencies such as the National Institute of Mental Health, which provided grants at the time to all MSW programs, the Children's Bureau, and the Veterans' Administration, all adopted some emphases on rural social work. One of the early grants provided for educational sessions at Indiana University and the University of Denver. Today there is a rural social work educators' caucus, an online journal, Contemporary Rural Social Work, and an annual institute on social work in rural areas that has operated continuously since 1976 at sites throughout the U.S.

I discovered, somewhat later, after I began writing about rural social work, that this was not a new initiative. Josephine Brown wrote in 1933 about rural social casework but somehow her work and several other earlier efforts were lost in the new approach to the subject. Emilia Martinez-Brawley's (1981) Seven Decades of Rural Social Work traces that history, which began with the Theodore Roosevelt administration in the early Twentieth Century to the inception of the Rural Caucus in the mid-seventies.

Many of Brown's ideas are similar to those I included in the earliest versions of my edited book (Ginsberg, 1976) and in the lectures and workshops I presented. Where did I 
get my ideas? For the most part, I made them up, based on a lifetime of small town connections and work with American Indian groups, rural Texas Eastern European contacts, rural Peace Corps centers, serving on the board of the now-defunct Rural America, Incorporated, and other places and organizations in which I lived and worked. The ideas of the domination by primary groups such as churches, families, and neighborhoods, and the importance of relating to and working with and through such groups were primarily based on personal experiences and informal conversations with rural residents. The issues of social policy and the American neglect of its rural areas were obvious and were also emphasized in President Johnson's National Advisory Commission on Rural Poverty (1967) report, The People Left Behind.

\section{Changes in Rural America}

The Huffington Post reported that the metropolitan-rural population differential had changed to 85 percent urban or metropolitan to 15 percent rural by 2011, the smallest rural proportion in American history (Yen \& Dreier, 2013). The rural or non-metropolitan population had consistently been 20 to 25 percent of the total since we began writing about rural social work, and stood at 72 percent in back in 1910 (Nusca, 2011). Yen and Dreier (2013) suggest that much of the change can be attributed to older adults leaving their rural homes for cities - often because of necessary and more broadly available health care and the other resources of American cities.

Rural areas, which include manufacturing and farming as well as scenic retirement spots, have seen substantial movement of residents to urban areas before. But the changes are now coinciding with sharp declines in U.S. birth rates and an aging population, resulting in a first-ever annual loss.

U.S. migration data show that older Americans are most inclined to live in rural counties until about age 74, before moving closer to more populated locations. The oldest of the nation's 76 million boomers turn 74 in 2020, meaning the window is closing for that group to help small towns grow (Yen \& Dreier, 2013, para. 12-13).

I noticed that my relatives in rural Texas towns such as Weimar and Halletsville moved to Houston and its suburbs as they advanced in age, confirming, for me, at least, that the Huffington Post observations are correct. Of course, many analysts point out that the rural population is also declining because many formerly rural towns have become suburbs of major metropolitan areas.

\section{Technology and Rural People}

The fifth and most recent edition of Social Work in Rural Communities (Ginsberg, 2011) includes two chapters on technology and its impact on rural people authored by Glenn E. Stone and Karen V. Harper-Dorton. These documents chronicle the major shifts in the lives of rural people. Innovations such as the Internet changed and are continuing to change the lives of people who live in smaller communities. Such remarkable changes were not foreseen by most writers when they envisioned the future. Now that the future 
has arrived, it is clear that technology, especially technology tied to the Internet, is the most important development in the lives of rural people.

When we discuss rural limitations and disadvantages several issues tend to arise: the lack of recreational and entertainment options; the lack of the ability to shop at reasonable prices for goods and services; the availability of health care services; and, economic opportunities, principally jobs. Many, but not all of these, are addressed by technological developments. For example, entertainment, which was once limited to movie theatres in metropolitan areas, is now available to anyone in the United States through sources such as Redbox and Blockbuster DVD kiosks, in both traditional DVD and Blu-Ray formats, almost everywhere for relatively low cost. Netflix, which relies on the U.S. Postal Service and the Internet, makes films available conveniently, rapidly, and at low cost. Many current and recent films are available to anyone with a TV cable connection through Video on Demand and various other video streaming services - often at a greater cost than those mentioned above but still significantly less than a typical pair of theatre tickets.

Rural people who invest in securities such as stocks and bonds can track their purchases and holdings on several Internet sites or on financial news networks such as CNBC. Whereas in the past investors had to visit investment companies to follow the markets, that kind of information is now readily and consistently available on TV or on the Internet. The theatre-style rooms in brokerage offices with stock information constantly displayed to a few interested investors are no longer necessary.

Perhaps the greatest entertainment developments are through social networking sites such as Facebook, Twitter, LinkedIn, and several smaller services, all readily accessible via computers, tablets, and smart phones. I first encountered the importance of these "social media" in the Los Angeles area when I stopped for dinner at an IHOP near the LAX airport. A young woman sitting across from me, whose male friend had departed for a while, was looking at her cell phone and smiling and laughing. I couldn't figure out what she was doing. Why would one stare at a telephone call? Later I realized that Californians were using social media sites. Like most American trends, that one began on the West Coast and spread across the nation.

Now, wherever we go, people are staring at their telephones and, on occasion, fingering them. At the movies or at plays, announcements forbid cell phones to be activated. Nevertheless, when the entertainment becomes tedious or dull, audience members turn immediately to "texting" and their social network memberships. Apparently, networks such as Facebook and Twitter provide unlimited entertainment, gossip, and news about people. Texting while driving has been documented as a major contributing factor in many automobile accidents and is extensive enough that several states have outlawed it. Notwithstanding the FAA's recent regulation change, most airlines have attempted, often unsuccessfully, to ban cell phone usage while their planes are airborne. Classrooms, which often permit note-taking by computer, are plagued by constant, sometimes noisy, pecking on cell phones and iPads. Even at home, I notice that my children and grandchildren and wife spend hours of their free time reading their cell 
phones and connecting with others on computers. The social networks are a major form of entertainment for many people.

As for shopping for clothing, technology hardware and software, toys, sporting goods, or almost anything else, rural people have access through the Internet to all kinds of sites and services that make it possible to purchase almost anything. The Amazon.com site literally sells everything - cosmetics, books, sports equipment, auto parts - although it began as a place to buy books at discount prices. Amazon owns Zappos, one of the largest vendors of shoes as well as clothing. Computer users can try on eyeglasses "virtually" and receive an assortment of frames to choose from before making a final selection. Several years ago, when I frequently traveled to New York, I always visited Forty Second Street Photo, a local chain of stores that sold name brand electronics at discount prices. It advertised regularly in the New York Times. But the stores are long gone. Now anyone, anywhere, can purchase all the electronics and photography equipment they want at competitive prices, which can be checked and compared on the Internet. A toll free telephone call or email will yield the purchase by mail, UPS or FedEx. So buying almost anything is available to rural residents through the Internet.

\section{Rural-Urban Inequalities}

Despite the technological advances described above, there are still some advantages in urban areas that are not available in rural communities and they are not likely to come to small towns to the extent necessary. Health care is one example. Most of the tertiary care hospitals are located in large urban areas, which may be distant from most small towns. Even office visits with physicians are limited. In Boone, North Carolina, a town with 15,000 permanent residents and a similar number of students at Appalachian State University, almost all of our medical visits are with physician assistants or nurse practitioners - usually quite talented and knowledgeable - rather than MDs. Vision services are often with optometrists rather than ophthalmologists. Those differences in care are not likely to change any time in the future.

Transportation in rural areas is still limited primarily to privately-owned automobiles. There is little public transportation except in special situations. In Boone, Appalachian State University and local government operate a free and efficient bus service available to anyone at no cost. The alternative would have been construction of extensive parking lots, which cause a variety of other problems.

Two major issues that remain unresolved despite the availability of technology are economic disadvantage and unemployment. Jobs are still scarce in rural areas although some corporations are decentralizing their operations to areas outside large cities. BMW operates a plant in Greer, South Carolina. Apple is constructing a facility in Maiden, North Carolina, and Google is doing the same in Lenoir, North Carolina. Honda, Hyundai, and Mercedes operate plants in several Alabama small towns, as does Toyota. So there is some relief to the endemic unemployment and underemployment in rural America. 


\section{Technology and Higher Education, Including Social Work Education}

Probably the single most revolutionary transformation in the preparation of social work practitioners has been the infusion of technology into higher education. Schools of social work began offering courses online, by television, and on media such as DVDs and videotapes in the latter decades of the Twentieth Century. According to Executive Vice Dean R. Paul Maiden, the University of Southern California School of Social Work offers the MSW throughout the United States wherever there are sufficient numbers to justify a class (personal communication, 2011). Much of the instruction is by means other than traditional classroom activities with students and professors in the same room. The cost differential for studying social work at Southern California or at a state university is significant. According to websites for the institutions mentioned, each semester's tuition at Southern California is $\$ 21,000$. At Appalachian State University, where I most recently taught, semester tuition and fees for North Carolina residents is $\$ 3,246$ and for residents of other states $\$ 9,356$. California state-supported universities such as UCLA charge in-state students about $\$ 6,500$ per semester and out of state students about $\$ 11,000$ per semester. At Indiana University, a full semester in the Graduate School costs about $\$ 5,000$ for residents and $\$ 15,000$ for non-residents. Of course, state universities in all states have some support from their state governments, although many of the most distinguished claim that state support amounts to less than half their budgets.

Duke University began offering its Master of Business Administration in nonresident ways several years ago. Harvard offers a number of non-degree programs throughout the year which allow participants to indicate they have studied at the nation's most prestigious university.

Largely non-resident institutions such as Webster University, Nova University, and Capella University, among others, offer extensive education away from traditional campuses. Some were seeking social work education accreditation as this was written. The University of Phoenix is another non-traditional institution that offers extensive higher education throughout the United States. Argosy, whose current president is a former social work education dean, is another.

Many, but not all, of the newer and non-traditional universities are proprietary, profitmaking businesses. Some are listed on stock exchanges as stockholder-owned corporations. These universities as well as many of those that are traditional, bricks and mortar institutions, advertise extensively. The competition for students has become increasingly intense. Potential students are recruited in the same ways other products and services are marketed in the United States, by newspaper, TV, and magazine advertising. I'm always a bit surprised to see, read, and hear pitches for education, which was once a staid and limited product.

Higher education administrators, noting the high costs of construction, find that education can be delivered technologically with minimal costs. One of the less often mentioned elements of technology is that information can be conveyed at little or no cost, once the infrastructure is developed for such information transmission. Signals delivered through the air or stored on "the cloud" are basically free as are most telephone 
communications. So a small investment in technology can save billions compared to constructing and maintaining traditional classrooms and laboratories.

Part of this trend is also a function of the pervasiveness of modern technology. College recruiters tell me that the first place students look for information on degrees are university websites. So keeping websites attractive and informative becomes one of the main strategies by which institutions promote themselves. Education referral services, which must earn fees for recruiting students, often pop up when one tries to access information about a college or university. For a while, every time I entered the term "social work" in an email document, which is most of the time, I was offered an opportunity to apply to the University of Southern California social work program. While doing research for this article, I entered the term social work and received an ad saying that if I had a BSW I could earn the MSW at Southern California in only one year.

TV advertising, especially during off-prime time hours when rates are lower, is also common and growing. Often the ads are for proprietary programs. Where I live, the most frequent ads are for ITT Technical programs and Virginia College - not the same, of course, as many of the long-standing universities and colleges in the state of Virginia. New Hampshire advertises an online college, which might be confused with the University of New Hampshire, the site of one of the best rural institutes in recent years and home of a distinguished school of social work. They're quite different institutions.

One also notices highly specialized advertising in specialized magazines. The B'nai $B$ 'rith Magazine, publishes several pages of ads each month for college and university programs, especially law schools, proclaiming their interest in Jewish applicants. Of course, disproportionate numbers of Jewish people seek university degrees, especially professional degrees. From a 2007 survey, the Pew Forum on Religion \& Public Life (2008) reported that 59 percent of American Jewish people have four or more years of college, exceeded only by American Hindus, 74 percent of whom have similar academic achievement. The Jewish community, which is traditionally located in metropolitan areas, has some outlets with a rural focus. The National Association of Jewish Federations is a fund raising and social planning organization principally for rural and small town Jewish residents. Organizations such as the South Carolina Jewish Historical Society regularly reports on Jewish backgrounds in rural communities, most of which disappeared long ago into metropolitan America. Ben Bernanke, former chair of the Federal Reserve, for example, grew up in Dillon, South Carolina, and played in the high school band there.

The online colleges typically advertise that they are "accredited." However, accreditation, as social work educators know well, comes in a variety of forms. Regional accreditation by one of the six accrediting bodies can give sanction to an institution but not necessarily to every degree it offers. For our own example, an accredited school or department of social work has to be associated with a regionally accredited institution (Middle States, Southern Association, Western Interstate Commission, etc.) and also accredited by the Council on Social Work Education, which has its own standards and accreditation procedures.

Online colleges have their own accrediting bodies such as the Accrediting Commission of the Distance Education and Training Council (DETC). Accreditation by 
that group does not imply regional accreditation or the specialized accreditation required for social work, nursing, and many other fields.

Many of the online and other non-traditional colleges and university students are eligible for government-guaranteed student loans and critics often suggest that some of those institutions survive financially because of those loans. Critics also suggest that the failure to pay back these loans is higher in non-traditional institutions than in the more traditional colleges and universities:

For-profit institutions continue to have the highest average two- and three-year cohort default rates at 13.6 percent and 21.8 percent, respectively. Public institutions followed at 9.6 percent for the two-year rate and 13 percent for the three-year rate. Private non-profit institutions had the lowest rates at 5.2 percent for the two-year rate and 8.2 percent for the three-year rate" (U.S. Department of Education, 2013, para. 6).

Of course, all colleges and universities depend, in part, on students receiving federally guaranteed loans. Some critics suggest that many of the degrees provided by nontraditional schools are less than valuable for seeking employment and becoming eligible for promotions.

\section{The Primacy of Money and Fund-Raising}

Money and the primacy of fund-raising needed to provide it have changed some older institutions that have not always seemed to need solicitations to keep themselves afloat. When an organization's primary focus becomes that of fund-raising it would seem to distort the organizational purposes and priorities.

For example, since my teenage years I have read Consumer Reports to help determine what to buy. In recent years, however, that publication has become more and more a fund-raising operation - seeking inclusion in their readers' estates, running sweepstakes, selling automobiles, and marketing specialized publications on various subjects such as health and finances. Recently, they ran an article in their main magazine on the best hospitals for surgery in various parts of the country. But to find detailed information on the subject, one had to subscribe to their health newsletter, in print or online.

AARP, which used to stand for the American Association for Retired Persons and now just stands for itself, sells Medicare supplement plans, automobile insurance, life insurance, and a host of other products and services. Of course, they, along with Consumer Reports, also advocate for policies affecting their spheres of interest such as older adults by AARP and product safety and quality by Consumer Reports.

My own work, before I moved to the Carolinas was as chief executive officer of higher education in West Virginia. The more I reflect on that position, the more I have come to believe that I was ill-suited for the job. Higher education is extensively about marketing and fund-raising. In state institutions, one of the major preoccupations is real estate - land, construction, and real estate regulation. Many of the board members are in the real estate business at one level or another. They may have some discussions of 
academics but the majority of the agendas in meetings of boards of trustees are about buying and selling land and constructing or renovating buildings. My own knowledge of these issues is minimal. I watch the newest president of the University of South Carolina, with whom I served as a dean colleague and in his purview when he became a vicepresident. He is masterful in discussing bond issues, interest rates, land acquisition, and construction, yet his professional background is public health. He is so good at his job that the university gave him a bonus if he would promise to stay in the presidency for the coming five years.

I wrote about these issues in the 1980s and was quoted in the Chronicle of Higher Education, suggesting that public officials and legislators were more interested in showing that they "got" a building for a local campus than they were in talking about their educational achievements. The reporter from the Chronicle said my comments astonished the reporters. They knew the same things but had never found a higher education officer who would discuss them.

\section{Conclusions}

Rural social work has changed over the years since this author personally began writing about the subject at West Virginia University. Some of those changes are discussed in this article. Technological changes have made large differences in the lives of rural Americans, who are a dwindling proportion of the American population, according to some analysts of the 2010 Census. Many of the non-economic elements of rural inequalities are mitigated by the developments in technology, especially the Internet, but economic and employment inequalities remain.

Technology is also changing social work education, especially the ways in which it is delivered. Earlier concerns about psychological orientations are no longer extensively discussed - or in most cases even remembered - in a very different social work environment that existed before the 1960s.

As this article has suggested, social work in rural areas is changing, partly because of technological developments. Education for professional social work is also changing, providing aspiring social workers with many more options for pursuing degrees such as the Bachelor of Social Work or the Master of Social Work. With the development of many new delivery systems, social work education is no longer as place-bound as it has been, historically. Students may pursue their studies in their own residential areas.

The costs of education and service delivery are also potentially reduced because of new technological developments. It is much less costly for educational institutions to play their roles economically. Perhaps the reduced costs will be reflected in future tuition and fee assessments.

In essence, rural social work may be in the process of equalizing with metropolitan social work and education for social workers may be changing in ways that make it less costly and less different than it has been in the past. 


\section{References}

Brown, J. C. (1993). The rural community and social case work. Social Service Review, 7(4), 691-693.

Cloward, R. A., \& Stein, H.D. (1958). Social perspectives on behavior: A reader in social science for social work and related professions. Glencoe, IL: Free Press.

Erikson, E. H. (1950). Childhood and society._New York, NY: W.W. Norton.

Federal Highway Administration. (2011, July 27). Census issues: Metropolitan planning and programming milestones. Washington, DC: Author. Retrieved from http://www.fhwa.dot.gov/planning/census issues/archives/metropolitan_planning/cps $\underline{2 \mathrm{k} . \mathrm{cfm}}$

Fraiberg, S. (1959). The magic years. New York, NY: Charles Scribner and Sons.

Ginsberg, L. H. (Ed.). (1976). Social work in rural communities. New York, NY: Council on Social Work Education.

Ginsberg, L. H. (Ed.). (2011). Social work in rural communities (5 $5^{\text {th }}$ ed.). Alexandria, VA: Council on Social Work Education Press.

Martinez-Brawley, E. (1981). Seven decades of rural social work: From country life to rural caucus. New York, NY: Praeger.

Nusca, A. (2011, July 28). Rural U.S. population lowest in history, demographers say. Retrieved from http://www.smartplanet.com/blog/smart-takes/rural-us-populationlowest-in-history-demographers-say/17982

Pew Forum on Religion \& Public Life (2008). U.S. Religious Landscape Survey. Report 1: Religious affiliation: Diverse and dynamic. Washington, DC: Author. Retrieved from http://religions.pewforum.org/pdf/report-religious-landscape-study-full.pdf

President's National Advisory Commission on Rural Poverty. (1967). The people left behind. Washington, DC: U.S. Government Printing Office.

Ross, M. G., \& Lappin, B. N. (1967) Community organization. New York, NY: Harper and Row.

Rozean, P. (1975). Freud and his followers. New York, NY: Knopf.

Saleebey, D. (Ed.). (2006). The strengths perspective in social work practice ( $4^{\text {th }} \mathrm{ed}$.). New York, NY: Pearson/Allyn and Bacon.

Skinner, B. F. (2011). About behaviorism. New York, NY: Harper and Row.

U.S. Census Bureau. (2012). 2010 census urban and rural classification and urban area criteria. Retrieved from http://www.census.gov/geo/reference/ua/urban-rural2010.html

U.S. Department of Education. (2013, September 30). Default rates continue to rise for federal student loans. Washington, DC: Author. Retrieved from 
http://www.ed.gov/news/press-releases/default-rates-continue-rise-federal-studentloans

Yen, H., \& Dreier, H. (2013, June 13). Rural population shrinking for first time in U.S. history, Census finds. Huffington Post. Retrieved from http://www.huffingtonpost.com/2013/06/13/rural-us-population-goesdown n $3433855 . \mathrm{html}$

\section{Author note}

Address correspondence to: Leon Ginsberg, Ph.D., 318 Leaning Tree Road, Columbia, SC 29223-3011. Email: leonleonginsberg@gmail.com

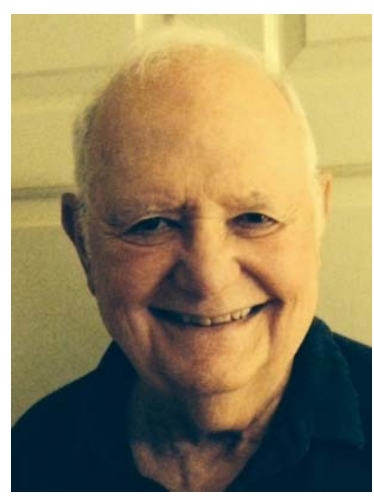

Leon Ginsberg teaches social work at the University of South Carolina and Appalachian State University. Recipient of the 2011 Council on Social Work Education Lifetime Achievement Award, Ginsberg led the Department of Social Work at Appalachian State and assisted with the Department's initial accreditation of its MSW program. He also served as Interim Chair of the Appalachian State Department of Physics and Astronomy after his completing his work with the Department of Social Work. From 1986 until his retirement in 2006, Dr. Ginsberg was Carolina Distinguished Professor at the University of South Carolina College of Social Work and served as its Dean during the last three of those years. Previously he served the state of West Virginia as Commissioner of the Department of Human Services and Chancellor of the Board of Regents for Higher Education and had been the Dean of the School of Social Work at West Virginia University. 